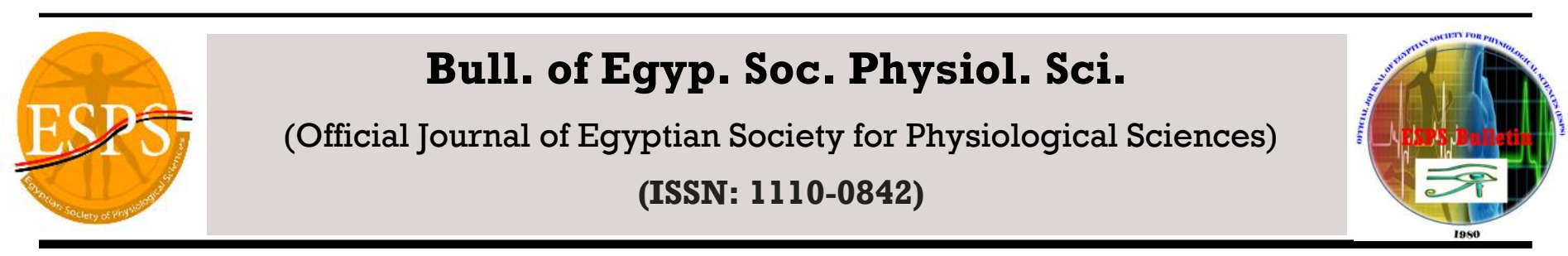

\title{
The Role of Fasudil and Ang (1-7) in PAN Induced Nephropathy in rats
}

\author{
Rehab E. Abo El gheit, Marwa N. Emam \\ Medical Physiology Department, Faculty of Medicine, Tanta University
}

Received: Sept 17, 2014 Accepted: Dec 5, 2104 Available online: Dec 20, 2014 by

\section{Abstract}

Background/Aim: : Nephrotic syndrome (NS) is a potentially life-threatening state characterized by heavy proteinuria, hypoalbuminemia and edema. The underlying pathological mechanisms are diverse and have not been fully elucidated. Several molecular processes have been implicated in its pathophysiology including the Rho-GTPases and renin-angiotensin (RAS) systems. We evaluated whether ROCK inhibition, through fasudil and RAS interfering through Mas agonist, AVE 0991 could have renoprotective effect, and whether it is comparable to well settled renoprotection of type-1 angiotensin II (AT1) receptor blocker, Losartan in Puromycin aminonucleoside (PAN)-induced nephropathy rat model.

Materials \& methods: Fifty adult male albino rats were divided into five groups (10 rats each), control (received $0.9 \% \mathrm{NaCl}$ ). PAN- nephrotic (PAN - injected rats received $0.9 \% \mathrm{NaCl}$ ), Fasudil treated PAN ( $30 \mathrm{mg} / \mathrm{kg} / \mathrm{d})$, Losartan treated PAN (10 mg/kg/ d ) and AVE 0991 treated PAN (3 mg/kg /d) group. All treated groups received treatment orally, from day 7 to day 14 of PAN injection.

RESULTS: PAN injection induced marked renal dysfunction indicated by significant $(P<0.05)$ proteinuria, hypoalbuminaemia, reduction in creatinine clearance and elevated serum creatinine associated with significant hyperlipidemia and increase in Tumor necrosis factor $-\alpha$ (TNF- $\alpha$ ), Creactive protein (C-RP) and urinary transforming growth factor $-\beta_{1}\left(\mathrm{TGF}-\beta_{1}\right)$. Treated groups with either fasudil or AVE0991, presented with significant improvement in kidney functions and lipid profile with parallel significant reduction in inflammatory and fibrogenic cytokines that was similar to the renoprotection observed with Losartan.

CONCLUSION: These data demonstrate that (RAS) and Rho-kinase pathways are involved in renal damage of NS, and their intervention could provide renoprotection and represent a novel therapy for NS.

Corresponding author: Marwa N. Emam, Medical Physiology Department, Faculty of Medicine, Tanta University, Egypt Mob.: 01224089068, Email : maroo_drmaroo@yahoo.com 


\section{INTRODUCTION}

NS is a clinical condition with a high morbidity and mortality that often leads to endstage renal failure with a high risk of cardiovascular complications due to severe hyperlipidemia (1).

At present, no promising therapy is available due to lack of understanding of signaling culprits involved in the pathogenesis of nephrosis (2). Unfortunately, these therapies only retard its progression, but do not prevent or reverse the renal function loss, indicating the need for additional therapeutic approaches (3).

RhoA, a member of the Ras superfamily of small GTP-binding proteins, and its down-stream effectors Rho associated kinases (ROCKs) are known to act as molecular switches controlling several critical cellular functions (4).

Accumulating evidence suggests that Rho/ (ROCK) signaling pathways may play important roles in kidney biology, which probably have homeostatic functions under normal physiological conditions, appear to be most highly activated under conditions of inflammation and injury and up-regulated in NS (5).

Fasudil is the first-generation Rho/ROCK inhibitor (6). It is the only Rho-kinase inhibitor practically available for long-term in vivo use (7). Fasudil is mainly metabolized to an active metabolite (hydroxyfasudil) when administered in vivo, this metabolite still retains activity with more selective sustained action than its parent drug on Rho-kinase. It specifically inhibits RhoA kinase activity by competing for ATP binding. It is mainly excreted by the kidney (8).
The new biologically active angiotensin (1-7) (Ang1-7), a metabolite of angiotensin I and II, is considered the most pleiotropic component of the (RAS), reported as a counter regulatory mediator of Ang II (9). It was detected at different nephron segments at both cortical and medullary regions of the kidney, acting at both glomerular and tubular sites, producing complex renal effects (10).

AVE 0991 is the first nonpeptide orally active analog of Ang (1-7), Mas receptor agonist, which has a 10-fold higher affinity for Mas receptor than Ang (1-7), AVE 0991 mimics Ang (1-7) effects in several organs including kidneys (11).

At present, the concept of the RAS as a dual axis system: one axis represented by angiotensinconverting enzyme (ACE)/AngII/AT1R and the other by ACE2/Ang-(1-7)/Mas has been settled (12). The balance between their activation plays an important role in the biological functions of different systems and an imbalance in these opposing pathways toward the ACE/AngII/AT1R axis predispose to many cardiovascular and renal diseases (13).

Losartan is a selective nonpeptite (AT1) receptor antagonist, has been applied in medical treatments of a variety of cardiovascular and renal diseases (14).

The observation that NS is frequently associated with over activation of RAS/Rho systems has drawn the attention to the possible interplay between the RAS and Rho axes. Such possibility was prompted by clinical trials and experimental studies (15).

The present study aimed to investigate whether Mas receptor activation with AVE 0991 and Rho Kinase inhibition by Fasudil, would have renoprotective effect in PAN induced NS, and 
whether this effect was relevant to the well-known renoprotection elicited by AT1 receptor blocker, Losartan treatment, that has been used widely as first-line therapy to reduce the progression of chronic renal diseases, with well-documented effectiveness.

\section{MATERIALS AND METHODS}

\section{Experimental Animals:}

All animal experiments were undertaken with approval of Ethical Animal Research Committee of Tanta University. Fifty adult male albino rats weighing (200-250g) were purchased from Faculty of Science (Tanta University). The animals were housed at temperature $22 \pm 2{ }^{\circ} \mathrm{C}$ and $12 \mathrm{~h}$ dark/light cycle throughout the study.

\section{Induction of experimental nephrotic syndrome:}

NS was induced by single intravenous injection of $70 \mathrm{mg} / \mathrm{kg}$ body weight of the puromycin amino nucleoside (PAN) (Sigma) diluted in 0.9\% saline (16). For consistency, day 0 was taken as the day of PAN injection. PAN -induced nephrosis is a well-described model of proteinuria, resembling the functional and morphological aspects of human minimal change disease or early stage focal segmental glomerulosclerosis (17).

\section{Experimental Protocol:}

Rats were randomly divided into five groups (10 rats each). Control group: received an equivalent volumes of sterile vehicle $(0.9 \% \mathrm{NaCl}$ solution). (PAN) nephrotic group: PAN - injected rats received an equivalent volume of sterile vehicle $(0.9 \% \mathrm{NaCl}$ solution). Fasudil treated PAN group: Fasudil (Sigma Aldrich) is given orally at a dose of $30 \mathrm{mg} / \mathrm{kg} / \mathrm{d}$, after PAN injection. Losartan treated PAN group: Losartan is given orally at a dose of $10 \mathrm{mg} / \mathrm{kg} / \mathrm{d}$, after PAN - injection. AV0991 treated PAN group: AV0991 (Aventis Pharma Deutschland, Frankfurt, Germany) is given orally at a dose of $3 \mathrm{mg} / \mathrm{kg} / \mathrm{d}$, after PAN - injection.

For the experiment, urine was collected from the day prior to PAN injection and on days 2 and 7 after injection. All treatment intervention started, after stabilization of proteinuria i.e. from the day (7) and continued until the end of experiment (till day 14), as an attempt to mimic the real clinical situation i.e. patients presented with some degree of injury, but not full blown renal damage. Previous studies have shown that in (PAN) rat model, daily urinary protein excretion was dramatically elevated on day 5 , reaching peak on day 9 and gradually return to normal level from day $15-27$ (2).

\section{Biochemical assay:}

At the end of the study period, rats in each group were individually housed in metabolic cage for $24 \mathrm{~h}$ urine collection. Total urine volume was measured; one ml was collected from the $24 \mathrm{~h}$ urine sample, and used for measurement of total proteinuria and Creatinine clearance.

\section{Collection of Blood Sample:}

Rats were decapitated. Blood was collected and centrifuged at $1000 \mathrm{rpm}$ and sera stored at $-20^{\circ} \mathrm{C}$ till biochemical analysis.

\section{The following biochemical parameters were} investigated:

Serum Creatinine was measured according to the alkaline picrate method (18). Serum albumin was measured according to method of Doumas (19). Serum total cholesterol was measured by 
enzymatic methods by using diagnostic kit (Biodiagnostic, Egypt) according to the method of Allain et al (20). Serum triglycerides were measured by enzymatic methods by using commercially available diagnostic kit (Biodiagnostic, Egypt) according to the method of Fossati and Prencipe (21). Total Urinary protein concentration was measured using the method of Bradford (22). Tumor necrosis factor- $\alpha($ TNF $-\alpha)$ was measured according to method of aderka (23) using TNF- $\alpha$ enzyme immunoassay kit (Biosciences, Egypt). C-reactive protein (C-RP) was measured by ELISA-based test kits according to Kindmark and Jean (24). Urinary TGF-ק1., since TGF- $\beta 1$ has been considered a potential biomarker of renal tissue fibrosis (25), this cytokine was measured in 24-hour urine samples. Level of TGF- $\beta 1$ in the urine was assessed by ELISA according to method of Tsakas (26). Sample of the urine were collected in metabolic cages and stored at $-20^{\circ} \mathrm{C}$. Until refrigeration, 10 $\mathrm{mL}$ of commercial protease inhibitor cocktail (Sigma Aldrich) were added at urine sample. Results were expressed as relative units of cytokine per mg of urinary creatinine.

\section{Statistical analysis:}

All values were expressed as mean \pm SD. Statistical analysis was performed by GraphPad Prism software, release 4.0 (GraphPad Software, San Diego, CA). The data obtained from various groups were statistically analyzed using unpaired $t$ test followed by one-way ANOVA. The $P$ value < 0.05 was considered to be statistically significant.
Effect of PAN injection, on kidney functions and lipid profile in experimental animals:

All experimental animals injected with PAN developed nephropathy characterized by marked renal injury as reflected by heavy proteinuria and hypoalbuminemia. As shown in table (1) \& figure (1), PAN injection, resulted in significant increase in proteinuria with significant reduction in serum albumin versus control group. Compared to control group, serum creatinine was significantly elevated together with significant reduction in creatinine clearance in PAN induced nephrotic group.

As shown in table (2) \& figure (2), PAN administration caused marked hyperlipidemia, where there was significant elevation in both total cholesterol and triglyceride levels compared to control group.

Effect of PAN injection, on fibrogenic and inflammatory biomarkers in experimental animals:

PAN injection resulted in significant increase in C-RP, TNF- $\alpha$ and in urinary TGF- $\beta_{1}$ compared to control group (table $3 \&$ figure 3 ).

Effect of ROCK inhibition and Mas receptor activation on kidney functions in PAN induced nephrotic rats:

As shown in table (1) \& figure (1), treatment with Rho Kinase inhibitor, fasudil had marked beneficial effects on PAN-induced renal dysfunction. There was significant reduction in urinary protein excretion associated with significant improvement in serum albumin compared with PAN induced nephrotic rats.

\section{RESULTS}


Indeed, serum creatinine was significantly decreased and creatinine clearance was significantly improved in fasudil treated nephrotic versus PAN induced nephrotic group.

Parallel experiments were carried out with the AT1 receptor antagonist, Losartan and Mas receptor agonist, AVE 0991 which had similar protective effects on renal parameters, to those of fasudil, suggesting cross talk between Rho/ (ROCK) signaling pathways and the RAS and their possible participation in pathogenesis of NS.

\section{Effect of ROCK inhibition and Mas receptor activation on lipid profile in PAN induced nephrotic rats:}

Fasudil treatment resulted in marked improvement in dyslipidemia (table $2 \&$ figure 2), there were significant reduction in total cholesterol and triglyceride level compared to nephrotic group. Comparable results obtained with both Losartan and AVE 0991 as shown in table (2) \& figure (2), there was significant reduction in nephrotic hyperlipidemia.

Effect of RhOK inhibition and Mas receptor activation on fibrogenic and inflammatory biomarkers in PAN induced nephrotic rats:

Fasudil treatment of PAN induced nephrotic rats resulted in significant reduction in C-RP, TNF- $\alpha$ and urinary TGF- $\beta_{1}$ levels (table 3 \& Figure 3 ). These results were similar to those obtained with Losartan and AVE0991 treatment with significant reduction in fibrogenic and inflammatory parameters.

Table (1): Effect of Rho Kinase inhibitor, Fasudil (30 mg/kg), Losartan (10 mg/kg) and Mas receptor agonist, AVE 0991 $(3 \mathrm{mg} / \mathrm{kg})$, on kidney functions in PAN induced nephrotic rats.

\begin{tabular}{|l|l|l|l|l|l|}
\hline \multicolumn{1}{|c|}{ Group } & control group & $\begin{array}{l}\text { PAN } \\
\text { nephrotic } \\
\text { group }\end{array}$ & $\begin{array}{l}\text { Fasudil } \\
\text { treated PAN } \\
\text { group }\end{array}$ & $\begin{array}{l}\text { losartan } \\
\text { treated PAN } \\
\text { group }\end{array}$ & $\begin{array}{l}\text { AVE0991 } \\
\text { treated PAN } \\
\text { group }\end{array}$ \\
\hline $\begin{array}{l}\text { Urinary proteins } \\
(\mathbf{m g} / \mathbf{2 4 h})\end{array}$ & $7.83 \pm 2.99$ & $110.02 \pm 24.42^{\mathrm{a}}$ & $68.59 \pm 26.74^{\mathrm{b}}$ & $71.899 \pm 21.536^{\mathrm{b}}$ & $73.37 \pm 16.56^{\mathrm{b}}$ \\
\hline $\begin{array}{l}\text { serum creatinine } \\
(\mathbf{m g} / \mathbf{d l})\end{array}$ & $0.45 \pm 0.212$ & $0.91 \pm 0.16^{\mathrm{a}}$ & $0.66 \pm 0.18^{\mathrm{b}}$ & $0.71 \pm 0.15^{\mathrm{b}}$ & $0.72 \pm 0.17^{\mathrm{b}}$ \\
\hline $\begin{array}{l}\text { Creatinine } \\
\text { clearance (ml/min) }\end{array}$ & $1.39 \pm 0.20$ & $0.58 \pm 0.10^{\mathrm{a}}$ & $0.86 \pm 0.10^{\mathrm{b}}$ & $0.84 \pm 0.11^{\mathrm{b}}$ & $0.81 \pm 0.14^{\mathrm{b}}$ \\
\hline $\begin{array}{l}\text { Plasma albumin } \\
(\boldsymbol{\mu g} / \mathbf{L})\end{array}$ & $2.551 \pm 0.47$ & $1.566 \pm 0.41^{\mathrm{a}}$ & $2.252 \pm 0.48^{\mathrm{b}}$ & $2.135 \pm 0.32^{\mathrm{b}}$ & $2.107 \pm 0.46^{\mathrm{b}}$ \\
\hline
\end{tabular}

${ }^{\mathrm{a}} \mathrm{P}<0.05$; versus control group. ${ }^{\mathrm{b}} \mathrm{P}<0.05$; versus $\mathrm{PAN}$ - induced nephrotic group . All values are expressed as mean $\pm \mathrm{SD}$ of 10 rats in each group.

Table (2): Effect of Rho Kinase inhibitor, Fasudil (30 mg/kg), Losartan (10 mg/kg) and Mas receptor agonist, AVE 0991 $(3 \mathrm{mg} / \mathrm{kg})$, on lipid profile in PAN induced nephritic rats.

\begin{tabular}{|l|c|c|c|c|c|}
\hline \multicolumn{1}{|c|}{ Group } & $\begin{array}{c}\text { control } \\
\text { group } \\
\text { parameter }\end{array}$ & $\begin{array}{c}\text { PAN } \\
\text { nephrotic } \\
\text { group }\end{array}$ & $\begin{array}{c}\text { Fasudil } \\
\text { treated PAN } \\
\text { group }\end{array}$ & $\begin{array}{c}\text { losartan } \\
\text { treated PAN } \\
\text { group }\end{array}$ & $\begin{array}{c}\text { AVE0991 } \\
\text { treated PAN } \\
\text { group }\end{array}$ \\
\hline $\begin{array}{l}\text { Total cholesterol } \\
\text { (mg/dl) }\end{array}$ & $84.43 \pm 14.55$ & $137.40 \pm 36.15^{\mathrm{a}}$ & $104.39 \pm 16.65^{\mathrm{b}}$ & $106.03 \pm 10.64^{\mathrm{b}}$ & $105.24 \pm 9.95^{\mathrm{b}}$ \\
\hline Triglyceride (mg/dl) & $77.63 \pm 11.14$ & $143.53 \pm 27.85^{\mathrm{a}}$ & $107.39 \pm 15.72^{\mathrm{b}}$ & $114.96 \pm 26.40^{\mathrm{b}}$ & $110.37 \pm 15.94^{\mathrm{b}}$ \\
\hline
\end{tabular}

${ }^{\mathbf{a}} \mathrm{P}<0.05$; versus control group. ${ }^{\mathrm{b}} \mathrm{P}<0.05$; versus $\mathrm{PAN}$ - induced nephrotic group . All values are expressed as mean $\pm \mathrm{SD}$ of 10 rats in each group. 
Table (3): Effect of Rho Kinase inhibitor, Fasudil (30 mg/kg), Losartan (10 mg/kg) and Mas receptor agonist, AVE 0991 $(3 \mathrm{mg} / \mathrm{kg})$, on fibrotic and inflammatory markers in PAN induced nephrotic rats.

\begin{tabular}{|c|c|c|c|c|c|}
\hline Group & $\begin{array}{l}\text { control } \\
\text { group }\end{array}$ & $\begin{array}{c}\text { PAN } \\
\text { nephrotic } \\
\text { group }\end{array}$ & $\begin{array}{c}\text { Fasudil } \\
\text { treated PAN } \\
\text { group }\end{array}$ & $\begin{array}{c}\text { losartan } \\
\text { treated PAN } \\
\text { group }\end{array}$ & $\begin{array}{c}\text { AVE0991 } \\
\text { treated PAN } \\
\text { group }\end{array}$ \\
\hline $\begin{array}{r}\text { Urinary TGF- } \beta 1 \\
\text { (R.U/mg creatinine) }\end{array}$ & 61.57 & $206.97 \pm 66.48^{\mathrm{a}}$ & $115.07 \pm 32.94^{b}$ & $120.08 \pm 33.44^{b}$ & $112.56 \pm 24.84^{b}$ \\
\hline C-RP (mg/dl) & & $0.31 \pm 0.07^{\mathrm{a}}$ & $0.24=$ & 0.25 & $0.246 \pm 0.040^{\mathrm{b}}$ \\
\hline TNF- $\alpha(\mathrm{ng} / \mathrm{ml})$ & $4.75 \pm 0.94$ & $7.40 \pm 1.39^{\mathrm{a}}$ & $5.99 \pm 1.17^{b}$ & $6.20 \pm 1.14^{b}$ & $6.16 \pm 0.73^{b}$ \\
\hline
\end{tabular}

TGF- $\beta 1$., Transgrowth factor $-\beta 1, \mathrm{C}-\mathrm{RP} ., \mathrm{c}-$ reactive protein ,TNF- $\alpha$., Tumor necrosis factor $-\alpha$

${ }^{\text {a }} \mathrm{P}<0.05$; versus control group. ${ }^{\mathrm{b}} \mathrm{P}<0.05$; versus $\mathrm{PAN}$ - induced nephrotic group

All values are expressed as mean $\pm \mathrm{SD}$ of 10 rats in each group.

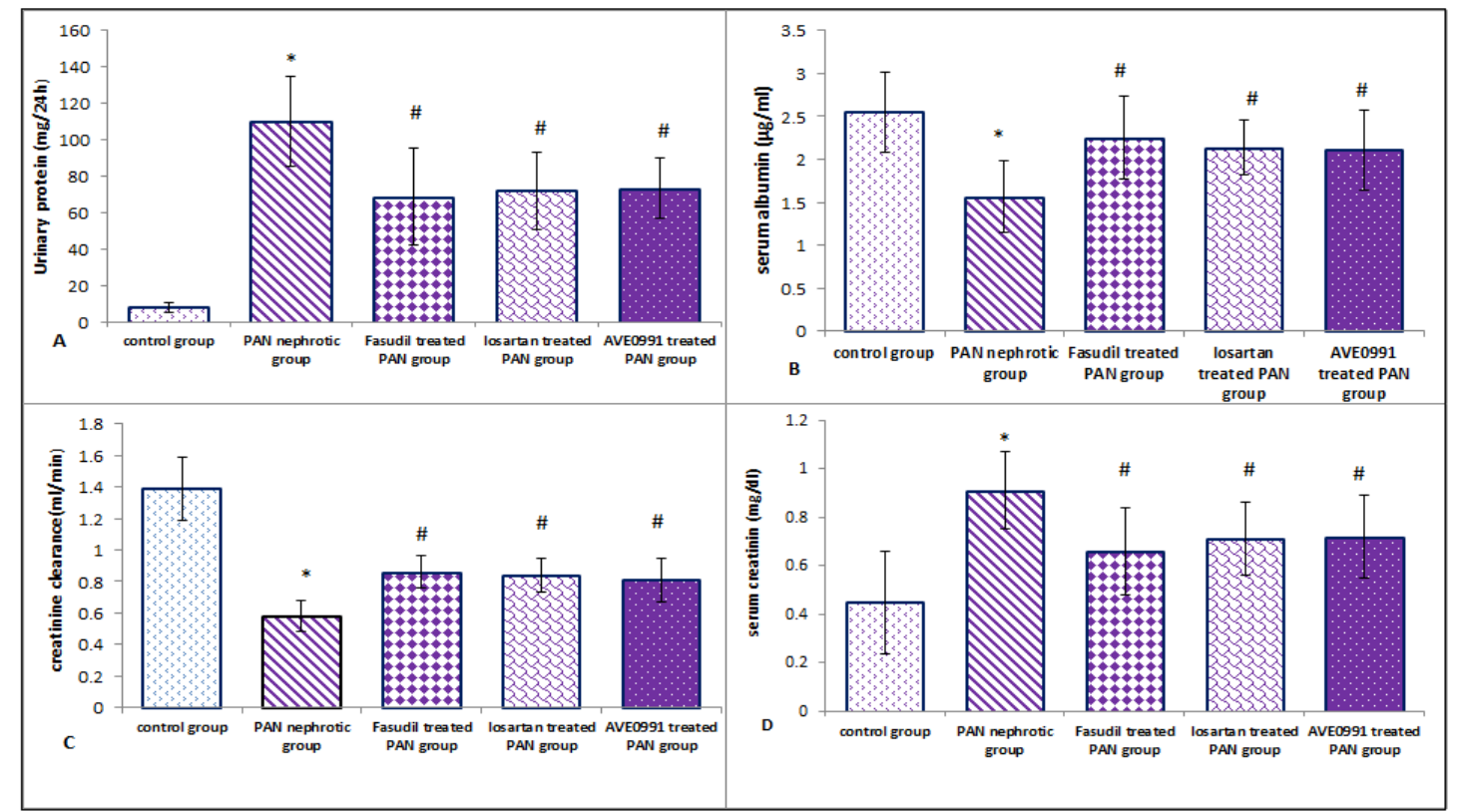

Figure (1): Effect of the treatment with Rho Kinase inhibitor, Fasudil, the Mas receptor agonist, AVE 0991 and the AT1 receptor blocker, Losartan on PAN induced renal injury. Data are means $\pm \mathrm{SD} .(n=10)$. ${ }^{*} \mathrm{P}<0.05$; versus control; \# P< 0.05 ; versus PAN- nephrotic group.

\section{DISCUSSION}

The major findings of the present study can be summarized as follows: (i) treatment with fasudil, significantly improved renal function parameters, reduced urinary protein loss with improved creatinine clearance and lipid profile in rat model of PAN-induced nephrosis (ii) The renoprotective actions of fasudil were very similar to those produced by Losartan and AVE 0991 (iii) The renoprotection obtained in our study was associated with parallel reduction in urinary level of the fibrogenic cytokine, TGF- $\beta_{1}$ and inflammatory biomarkers, TNF- $\alpha, \mathrm{C}-\mathrm{RP}$.

Multiple mechanisms have been suggested to explain the protective role of Rho-kinase inhibitor, fasudil in the nephrotic diseases. Among them the effect of fasudil on renal microvascular tone ,where fasudil dilates both afferent and efferent arterioles with prominent action on afferent arterioles, mediating glomerular hemodynamics changes involving autoregulation of glomerular 


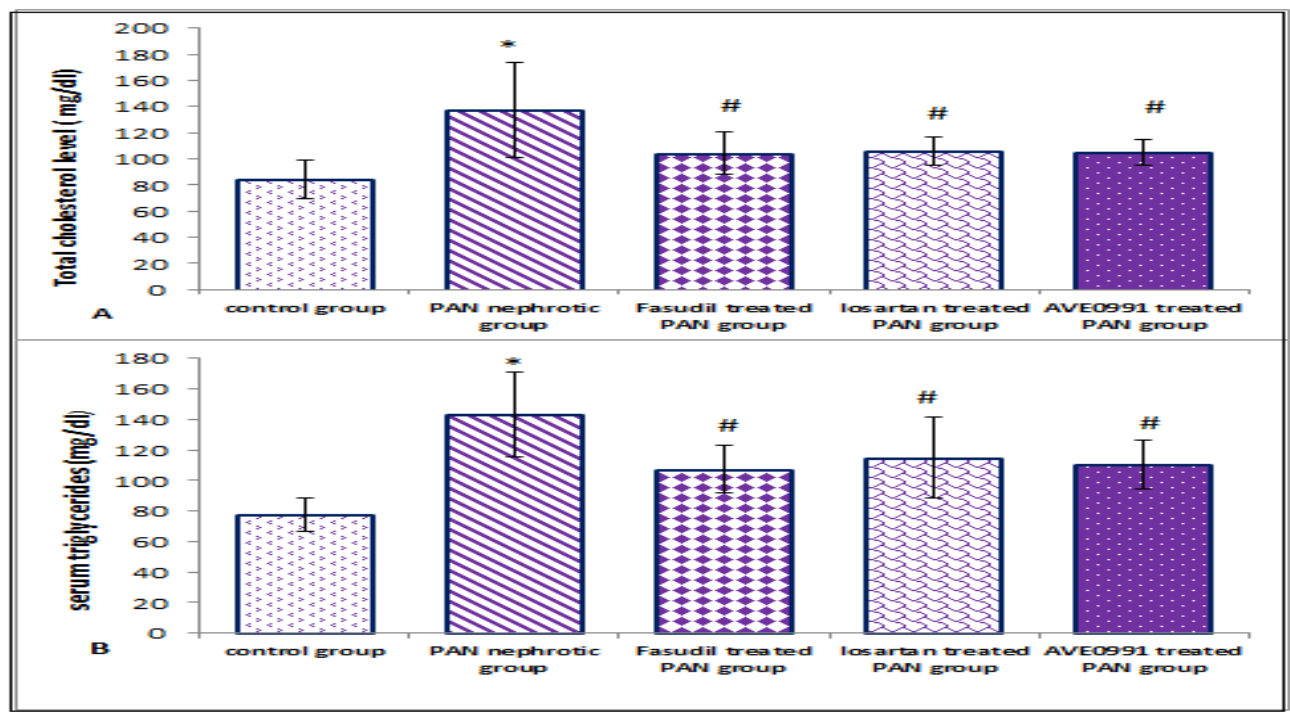

Figure (2): Effect of the treatment with Rho Kinase inhibitor, Fasudil, the Mas receptor agonist, AVE 0991 and the AT1 receptor blocker, Losartan on lipid profile in PAN induced nephrotic rats. Data are means $\pm \mathrm{SD}(n=10) .^{*} \mathrm{P}<0.05$; versus control; \# P $<0.05$; versus PAN- nephrotic group.

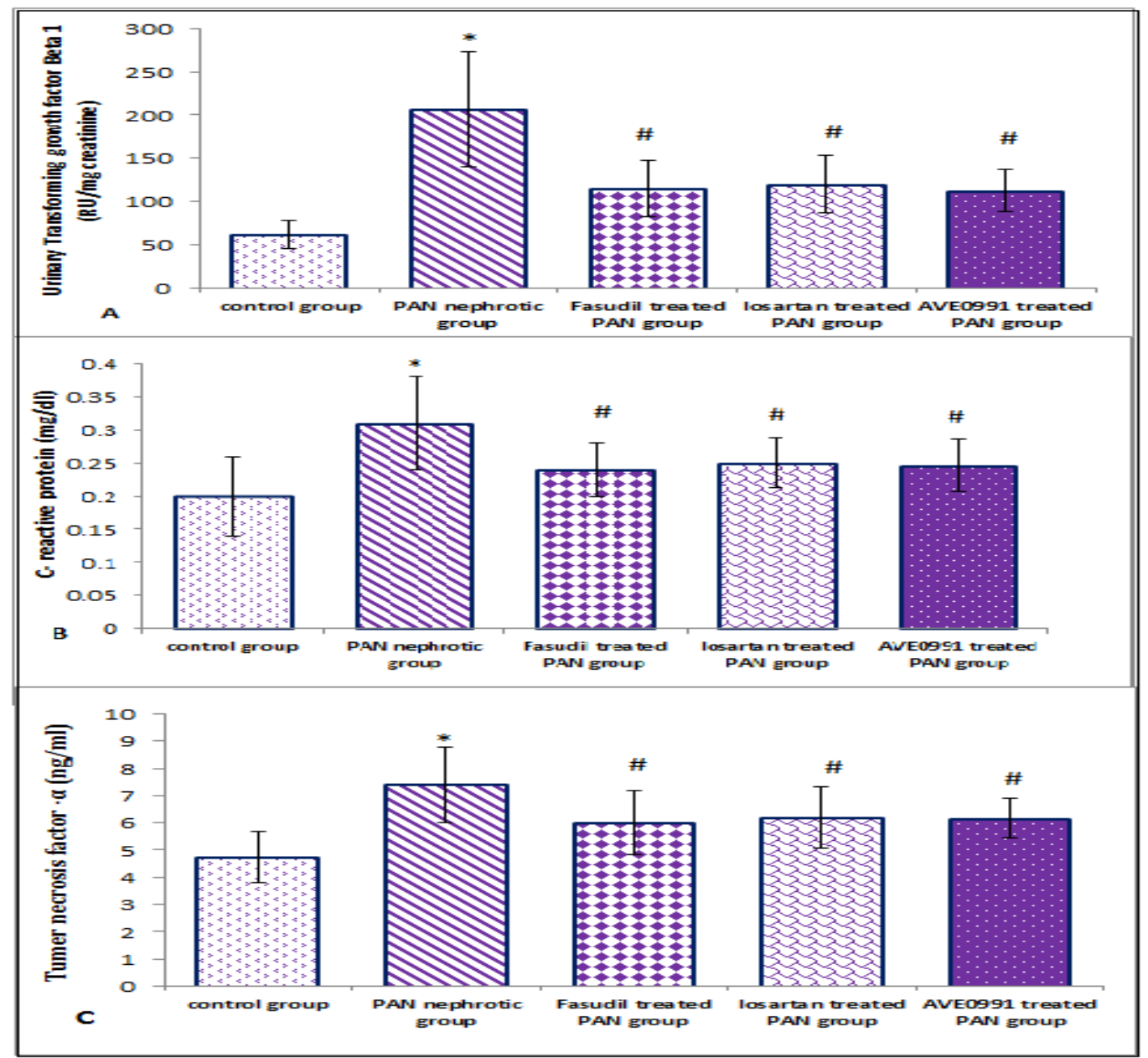

Figure (3): Effect of the treatment with Rho Kinase inhibitor, Fasudil, the Mas receptor agonist, AVE 0991 and the AT1 receptor blocker, Losartan on fibrotic and inflammatory cytokines in PAN induced nephrotic rats. Data are means \pm SD. $(\mathrm{n}=10)$. $* \mathrm{P}<0.05$; versus control; \# $\mathrm{P}<0.05$; versus $\mathrm{PAN}$ - nephrotic group. 
filtration rate and renal blood flow, through myosin light chain phosphatase inhibition, which promotes phosphorylation of myosin light chains and smooth muscle contraction . Moreover fasudil could modify renal Rho-kinase activity probably through decreased mechanical stress (27).

The renal protective effect of fasudil, may also be explained by decreasing the loss of glomerular nephrin expression at both the mRNA and protein levels, maintaining the integrity of the glomerular filtration barrier. It is proved through several in vivo studies, in human and animal that nephrin level is decreased in NS (28). Hidaka $\mathrm{T}$ et al demonstrated previously that fasudil reversed AngII induced the down-regulation of nephrin expression in podocytes (29).

Fasudil could preserve podocyte viability via stabilization of particular a slit diaphragm proteins, so attenuating progressive podocyte injury, recorded in NS (30).

The antioxidant effects of fasudil reported previously in hypercholesterolemic rats (31).The antioxidant effect of fasudil could be attributed not only to direct inhibition of ROS production through down-regulation of NADPH oxidases(32), but also indirectly through inhibition of oxidative stress - induced expression of pro-inflammatory cytokines and adhesion molecules (33) .

Kanda et al., (34) documented anti-proliferative, anti- inflammatory effects of fasudil through upregulated expression of a cyclin-dependent kinase inhibitor, p27kip1 in renal tissues which safeguards against inflammatory injury and counter abnormal cell growth.

Fasudil, could obliterate many injury promoting effects associated with Rho- signaling cascades, that proved to be implicated in nephrosis, through decreasing the expression of TGF- $\beta$ mRNA (35), that upregulated significantly in the renal cortex of PAN models(36), and suppress both extracellular matrix accumulation and $\alpha$-SMA expression (37) and its associated signal pathways mediated TGF- $\beta$ effect(38).

Recent findings derived from targeting ROCK inhibition , recorded the potential role of fasudil as antiapoptotic in CsA induced nephropathy model, through modulation of mitogen-activated protein kinase (28), and as anti-inflammatory in the unilateral ureteral obstruction model, mediated by inhibition of macrophage migration and proliferation (39) .

The renoprotective effect of fasudil, associated with improved lipid profile in PAN nephrosis, supporting the fact that Rho-kinase constitutes a critical determinant acting as a key mediator for cross-talk between metabolic and hemodynamic abnormalities in renal diseases. Statins that proved to inhibit the biological actions of Rho, reported as first-line agents in the management of nephrotic dyslipidemia, through inhibiting the early step in the cholesterol synthesis (30). Kikuchi Yet al., (40) reported improved dyslipidemia with fasudil, at least in part, through the improved adipocyte differentiation.

The favorable effect of fasudil may be augmented by inhibition of its elimination in nephrosis as its metabolite; hydroxyl fasudil is mainly excreted by the kidney (8).

Oral administration of the Mas receptor agonist, AVE 0991 significantly improved renal function parameters, improved dyslipidemia.Several studies have shed more light on the underlying molecular mechanisms behind the effect of AVE 0991, including NO synthase phosphorylation, 
phospholipase A2 stimulation and consequently release of arachidonic acid for prostanoid production and finally, prostacyclin-mediated production of cAMP and activation of cAMPdependent protein kinase, leading to increase NO, prostaglandins production and bioavailability (41).

AVE0991, could have antiproliferative , antiinflammatory effect, that was explained by down regulating the mitogen-activated protein kinase cascade, particularly p38 $\quad$ MAPK phosphorylation(42) ,COX (cyclooxygenase)-2 reduction (43), or by modulating ROS production through inhibited NADPH oxidase expression, contributing to the renoprotection (44) .

Our data regarding decreased urinary TGF- $\beta 1$ level with AVE 0991 administration, support an anti-fibrogenic role for ACE2-Ang-(1-7)-Mas receptor axis at renal tissue, that could attributed either to decrease TGF- $\beta$ levels or expression in rat proximal tubular cells . The renoprotective effect of AVE 0991, previously reported by Silveira et al.,(10), Giani et al.,(45) and Barroso et al., (46).

The beneficial effect of AVE0991, on dyslipidemia in our model could be attributed to the Ang-(1-7)-induced lipolysis via a Mas/PI3K/eNOS signaling pathway $(9,47)$.

The renoprotective action of Losartan, recorded previously in nephrotic model (48), clearly involve multiple pathways including preserved glomerular nephrin expression (49), antiproliferative effect through prostaglandins stimulation and cAMP production (50), anti-inflammatory effect, through reduction of pro-inflammatory cytokines asTNF- $\alpha$, IFN- $\gamma$, suppressed expression of inflammatory genes (51) and increase of the anti-inflammatory cytokine, IL-10 and decreases leukocyte endothelial cell interactions (52).
The proximal renal tubule is innervated by renal sympathetic nerve termini, whose subsequent catecholamine release in turn stimulates $\alpha 2 / \beta 1$ receptors. AT1 receptors are located at the nerve terminals. Losartan is also able to attenuate activation of the intrarenal renin-angiotensin system by inhibiting renal sympathetic outflow (53) .

Extensive evidence suggests a direct link between the RAS and TGF- $\beta$, concluding TGF- $\beta 1$ as Ang II downstream (54) . Reduced urinary TGF- $\beta_{1}$ level observed with losartan, reflected the antifibrotic role that could be explained by reduced the renal TGF- $\beta$ mRNA expression with inhibition of the Smad2 pathway(55), as suggested previously by Crowley et al(56). Another possible antifibrotic TGF- $\beta$-independent mechanism could be elicited by Losartan, is blocking the Ang IIstimulated phosphorylation and activation of ERK1 and ERK2 and MAPK activity (57).

The antiproteinuric effect of Losartan relies on the decrease in glomerular pressure due to their preferential vasodilatory effect on the glomerular efferent arterioles, rather than on their antihypertensive effect per se, However direct podocyte protection can't be excluded (58) .

The improvement in nephrotic proteinuria and hypoalbuminemia observed with Losartan, is expected to reduce hyperlipidemia since those conditions contribute independently to the impaired lipoprotein catabolism in NS (59). In addition, Losartan may have a direct lowering effect on plasma triglyceride concentration, even though direct effects on intrinsic mechanisms resulting in NS cannot be ruled out (2), which could contribute to the overall effect of Losartan .

Several works demonstrated AT1 receptor blockers, including Losartan, associated with 
altered balance between Ang II and Ang-(1-7), with increased endogenous Ang-(1-7) level by as much as 25-fold (60) .Moreover, the Losartan effects were blunted in mice with genetic deletion of Mas receptor (61),supported by the immunohistochemical data, which have shown a similar distribution for Ang-(1-7), ACE2 and Mas within the kidney, placing the key components together for activation (10) .

Taken together, these findings indicated that ACE2/Ang-(1-7)/Mas receptor axis activation participate in the renoprotection triggered by Losartan, and AVE0991 (through Mas) and Losartan have many overlapping actions.

The results obtained with fasudil were comparable to those of Losartan and AVE0991.This is supported by the fact that AT1 receptors activation has been linked to Rho activation (62). The expression of Rho-kinase itself is accelerated by ang II (63). More importantly, Rho-kinase is substantially involved in the vascular effects of ang II (8). Indeed, some of the beneficial effects of AT1 receptors blockers in disease processes may be mediated by decreasing ANG2-dependent Rho activation .So it is possible that some of the beneficial effects of ROCK inhibition in the present study are mediated by antagonizing downstream effectors of ANG2dependent Rho activation. So several lines of evidence assumed that Rho-kinase inhibitors could cover the pharmacological effects of many conventional drugs, including statins, (ACE) inhibitors, AT1 receptor blockers (64).

Conclusion: Based on the overall promising studies and the results obtained from the current investigation, we may conclude that RAS / RHO systems have important implications in NS and constitute an important determinant as a central molecule linking several underlying pathological process. So ROCK inhibition or Ang-(1-7)/Mas activation, could obliterate many injury promoting effects associated with underlying signaling cascades and could be a good candidate for treating NS and its complications, but further researches should be done to strengthen our results.

In any case, new opportunities and questions emerge to resolve the complexity of renal nephrosis and discovery of possible new drugs directed to intracellular signal transduction pathways such as AVE0991 and fasudil that may be combined with the classical treatment schemes for more effective therapy.

\section{REFERENCES}

1. Trimarchi H. Primary focal and segmental glomerulosclerosis and soluble factor urokinase-type plasminogen activator receptor. World J. Nephrol.; 2 (4):103-102 (4):103-10 (2013).

2. Doucet A., Favre G. and Deschênes G. Molecular mechanism of edema formation in nephrotic syndrome: therapeutic implications. Pediatr Nephrol.; 22:1983-1990 (2007).

3. Appel GB. and Appel AS. New diagnostic tests and new therapies for glomerular diseases. Blood Purif.; 35 (1-3):81-5 ( 2013).

4. Deng J., Feng E., Ma S., Zhang Y. and Li J. Design and synthesis of small molecule RhoA inhibitors: a new promising therapy for cardiovascular diseases? J Med Chem.; 54 (13):4508-22 (2011). 
5. Impellizzeri D., Mazzon E., Paterniti I. and Cuzzocrea S. Effect of Fasudil, a Selective Inhibitor of Rho Kinase Activity, in the Secondary Injury Associated with the Experimental Model of Spinal Cord Trauma . JPET.; 343 : 121-33 (2012).

6. Raja SG. Evaluation of clinical efficacy of fasudil for the treatment of pulmonary arterial hypertension. Recent Pat Cardiovasc Drug Discov.; 7 (2):100-4 (2012).

7. Kanda T., Wakino S. and Homma K. Rhokinase as a molecular target for insulin resistance and hypertension. FASEB J.; 20 (1):169-71(2006).

8. Dong M., Yan B., Liao JK., Lam YY. and Yu CM. Rho-kinase inhibition: a novel therapeutic target for the treatment of cardiovascular diseases. Drug Discov. Today; 15 (0): 622-629 (2010).

9. Silva DG., Braga VT. and Santos RA. Angiotensin-(1-7): beyond the cardio-renal actions. Clin. Sci. (Lond).; 124 (7):443-56 (2013).

\section{Silveira KD, Barroso LC, Vieira AT,} Cisalpino D and Lima CX. Beneficial effects of the activation of the angiotensin-(1-7) MAS receptor in a murine model of adriamycininduced nephropathy. PLoS One; 8 (6): 66-82 (2013).

\section{Santos RAS and Ferreira AJ.} Pharmacological Effects of AVE 0991, a Nonpeptide Angiotensin-(1-7) Receptor Agonist. Cardiovascular Drug Reviews; 24 (34) : 239-246 (2006).
12. Ferrario CM. and Varagic J. The Ang-(17)/ACE2/mas axis in the regulation of nephron function. Am. J. Physiol. Renal. Physiol.; 298: 1297-1305 (2010).

13. Ocaranza MP. and Jalil JE. Protective Role of the ACE2/Ang-(1-9) Axis in Cardiovascular Remodeling. Int. J. Hypertens ; 2012: 594361(2012).

14. Smink PA, Miao Y, Eijkemans MJ, Bakker SJ, Raz I and Parving HH. The importance of short-term off-target effects in estimating the long-term renal and cardiovascular protection of angiotensin receptor blockers. Clin Pharmacol Ther. ; 95 (2):208-15 (2014).

15. Iwai M. and Horiuchi M. Role of the ACE2/angiotensin1-7/Mas axis in the cardiovascular system. Hypertension Research; 33:1108-1109 (2010).

16. Takashima K., Nishiyama CM. Kuroda J. and Sato F. Renoprotective effect of the L/Ntype calcium channel antagonist cilnidipine on puromycin aminonucleoside- induced nephrosis in rats. Arzneimittelforschung; 59 (2):79-85 (2009).

17. Schell C. and Huber TB. New players in the pathogenesis of focal segmental glomerulosclerosis. Nephrol Dial Transplant.; 27 (9):3406-12 (2012).

18. Haeckel R. Assay of creatinine in serum, with use of Fuller's Earth to remove interferents. Clin Chem.; 27:179-83 (1981).

19. Doumas B. and Watson WA. "Standard measurement of serum albumin with 
bromocresolgreen." Clin. Chem. Acad. Press.; 31: 87-96 (1971).

20. Allain CC., Richmond W. and Poon LS. Enzymatic determination of total serum cholesterol. Clin Chem.; 20 (4):470-5 (1974).

21. Fossati P. and Prencipe. Serum triglycerides determined colorimetrically with an enzyme that produces hydrogen peroxide. Clin. Chem.; 28 (10):2077-80 (1982).

22. Bradford MM. A rapid and sensitive method for the quantitation of microgram quantities of protein utilizing the principle of proteindye binding. Anal Biochem; 72: 248-254 (1976).

23. Aderka K. and Maor Y. "Measurement of bioactivity of TNF- $\alpha . "$ J. Exp. Med.; 175: 323329 (1992).

24. Kind mark C. Quantitative measurement of C-reactive protein in serum. Clinica. Chimica. Acta; 26 (1): 95-98 (1969).

25. Kaysen G. Plasma composition in the nephrotic syndrome. Am. J. Nephrol.; 13 (5):347-59 (1993).

26. Tsakas S. and Goumenos DS. Accurate measurement and clinical significance of urinary transforming growth factor-beta1. Am. J. Nephrol.; 26: 186-193 (2006).

27. Sharpe C. and Hendry BM. Signaling: Focus on Rho in Renal Disease. JASN.; 14 (1):261-4 (2003).

28. Park JW., Park CH., Kim IJ. and Kim SW. Rhokinase inhibition by fasudil attenuates cycl osporine induced kidney injury. J. Pharmacol. Exp. Ther.; 338 (1): 271-9 (2011).
29. Hidaka T., Suzuki Y., Yamashita M., Shibata T. and Horikoshi S. Amelioration of crescentic glomerulonephritis by RhoA kinase inhibitor, Fasudil, through podocyte protection and prevention of leukocyte migration. Am. J. Pathol.; 172 (3):603-14 (2008).

30. Shibata S., Nagase $M$. and Fujita $T$. Fluvastatin Ameliorates Podocyte Injury in Proteinuric Rats via Modulation of Excessive Rho Signaling. J. Am. Soc. Nephrol.; 17: 754764 (2006)

31. Ma Z. , Zhang J., Li G. and Chu L. Rho kinase inhibition by fasudil exerts antioxidant effects in hypercholesterolemic rats. Clin. Exp. Pharmacol. Physiol.; 38 (10):688-94 (2011).

32. Shi J and Wei L. Rho kinases in cardiovascular physiology and pathophysiology: the effect of fasudil. J. Cardiovasc. Pharmacol.; 62 (4): 10 (2013).

33. Lu Y, Li H, Jian W, Zhuang J, Wang K and PengW. The Rho/Rho-associated protein kinase inhibitor fasudil in the protection of endothelial cells against advanced glycation end products through the nuclear factor $\kappa \mathrm{B}$ pathway. Exp. Ther. Med.; 6 (2): 310-316 (2013).

34. Kanda T., Wakino S., Homma K. and Saruta T. Effect of fasudil on Rho-kinase and nephropathy in subtotally nephrectomized spontaneously hypertensive rats. Kidney International; 64: 2009-2019 (2003).

35. Wu G., Tu Y., and Jia R. The influence of fasudil on the epithelial-mesenchymaltrans differentiation of renal tubular epithelial cells 
from diabetic rats. Biomed. Pharmacother.; 64:124-129 (2010).

36. Grygielko ET., Martin WM. and Tweed C. Inhibition of Gene Markers of Fibrosis with a Novel Inhibitor of Transforming Growth Factor- $\beta$ Type I Receptor Kinase in PuromycinInduced Nephritis. JPET.; 313 (3): 943951(2005).

37. El-Gohary Y., Tulachan S., Wiersch J.and Welsh C. A smad signaling network regulates islet cell proliferation. Diabetes; 63 (1): 224-36 (2014).

38. Derynck R. and Zhang YE. Smad-dependent and Smad-independent pathways in TGFbeta.family signalling. Nature; 425:577-584 (2003).

\section{Satoh S., Yamaguchi T., Sato N., Asano T} and Shimokawa H. Fasudil attenuates interstitial fibrosis in rat kidneys with unilateral ureteral obstruction. Eur. J. Pharmacol.; 455:169-174 (2002).

40. Kikuchi Y., Yamada M. and Imakiire T. A Rho-kinase inhibitor, fasudil, prevents development of diabetes and nephropathy in insulin-resistant diabetic rats. Journal of Endocrinology; 192: 595-603 (2007).

41. Sampaio WO., Silva FR. ,Schiffrin El. and Touyz RM. Angiotensin-(1-7) through receptor mas mediates endothelial nitric oxide synthase activation via Akt-dependent pathways. Hypertension; 49: 185- 192 (2007).

\section{Su Z., Zimpelmann J. and Burns KD.} Angiotensin-(1-7) inhibits angiotensin IIstimulated phosphorylation of MAP kinases in proximal tubular cells. Kidney Int.; 69 (12):2212-8 (2006).

43. Clark MA., TallantEA., Tommasi E., Bosch S. and Diz DI. Angiotensin-(1-7) reduces renal angiotensin II receptors through a cyclooxygenase-dependent mechanism J. Cardiovasc. Pharmacol.; 41 (2):276-83 (2003).

44. Long SC., Xin YW., Yi H., Ming F. and Li YC. AVE0991, a Nonpeptide Compound, Attenuates Angiotensin II-Induced Vascular Smooth Muscle Cell Proliferation via Induction of Heme Oxygenase-1 and Downregulation of p-38 MAPK Phosphorylation. Int. J. Hypertens.; 2012:1-8 (2012).

45. Giani JF., Burghi V., Veiras LC., Tomat A. and Cao G. Angiotensin-(1-7) attenuates diabetic nephropathy in Zucker diabetic fatty rats. Am. J. Physiol. Renal Physiol.; 302 (12): 1606-1615 (2012).

46. Barroso LC., SilveiraKD., Lima CX. and Rachid M. Renoprotective Effects of AVE0991, a Nonpeptide Mas Receptor Agonist, in Experimental Acute Renal Injury. Int. J. Hypertens.; 2012: 808726 (2012).

\section{Oh YB, Kim JH, Park BM, Park BH and} Kim SH. Captopril intake decreases body weight gain via angiotensin-(1-7). Peptides; 37 (1):79-85. (2012).

48. Iturbe BR., Sato T., Quiroz Y. and Vaziri N. AT-1 receptor blockade prevents proteinuria, renal failure, hyperlipidemia, and glomerulosclerosis in the Imai rat. Kidney International; 66: 668-675 (2004). 
49. Benigni A., Tomasoni S., Gagliardini E., Grunkemeyer JA. and Remuzzi G. Blocking angiotensin II synthesis/activity preserves glomerular nephrin in rats with severe nephrosis. J. Am. Soc. Nephrol.; 12: 941-948 (2001).

50. Sampaio WO., Henrique de Castro C., Santos RA., Schiffrin EL. and Touyz RM. Angiotensin-(1-7) counter regulates angiotensin II signaling in human endothelial cells. Hypertension; 50: 1093-1098 (2007).

51. Merino A, Antonia $M$ and Lara A . Losartan prevents the development of the proinflammatory monocytes $\mathrm{CD}^{+} 4^{+} \mathrm{CD} 16^{+}$in haemodialysis patients. Nephrol. Dial. Transplant. 0: 1-6 (2012).

\section{Sukumaran V., Veeraveedu PT., Gurusamy} N. and Lakshmanan AP. Telmisartan acts through the modulation of ACE-2/ANG 1$7 /$ mas receptor in rats with dilated cardiomyopathy induced by experimental autoimmune myocarditis. Life Sci.; 90 (7-8): 289-300 (2012).

53. Muñoz M., Rincón J. and Pedreañez A. Pro inflammatory role of angiotensin II in a rat nephrosis model induced by Adriamycin. Journal of the Renin-Angiotensin-Aldosterone System; 12 (4): 404-412 (2011).

54. Rosenkranz S. TGF-beta1 and angiotensin networking in cardiac remodeling.Cardiovasc. Res.; 63 (3): 423-432 (2004).

55. Zeng W., Chen W., Leng X., He JG. and Ma H. Chronic angiotensin-(1-7) administration improves vascular remodeling after angioplasty through the regulation of the TGF-beta/Smad signaling pathway in rabbits. Biochem. Biophys. Res. Commun.; 389 (1): 138-144 (2009).

56. Crowley SD., Vasievich MP., Ruiz P. and Parsons K. Glomerular type 1 angiotensin receptors augment kidney injury and inflammationin murine autoimmune nephritis. J ClinInvest.; 119: 943-953 (2009).

\section{Tallant EA., Ferrario CM. and Gallagher} PE. Angiotensin-(1-7) inhibits growth of cardiac myocytes through activation of the mas receptor. Am. J. Physiol. Heart Circ. Physiol.; 289 (4): 1560-1566 (2005).

58. Shimizu A., Zhong J., Miyazaki Y., Hosoya T. and Ichikawa I. ARB protects podocytes from HIV-1 nephropathy independently of podocyte AT1. Nephrol. Dial. Transplant.; 27: 3169-3175 (2012).

59. Schena FP. Biomarkers and personalized therapy in chronic kidney diseases. Expert Opin. Investig. Drugs; 26:1-4 (2014).

60. Ferrario CM, Gallagher PE, Averill DB, Brosnihan KB and Tallant AE. Effects of renin-angiotensin system blockade on renal angiotensin-(1-7) forming enzymes and receptors. Kidney Int.; 68 (5):2189-96 (2005).

61.Pinheiro SV., Ferreira AJ., Kitten GT., da Silveira KD. and da Silva DA. Genetic deletion of the angiotensin-(1-7) receptor Mas leads to glomerular hyperfiltration and microalbuminuria. Kidney Int.; 75: 1184-1193 (2009).

62.Wang L., Ellis MJ. , Fields TA. and SpurneyRF.Beneficial effects ofthe Rho kinas 
e inhibitor Y27632 in murine puromycin amino nucleoside nephrosis. Kidney Blood Press Res.; 31(2):111-21 (2008).

\section{Hiroki J, Shimokawa H, Higashi M,} Morikawa K, Kawamura N and Takeshita
64.Shimokawa H. and Takeshita A. Rho-Kinase Is an Important Therapeutic Target in Cardiovascular Medicine. Arterioscler. Thromb. Vasc. Biol.; 25:1767-1775(2005).

A. Inflammatory stimuli upregulate Rho-kinase in human vascular smooth muscle. J. Mol. Cell. Cardiol.; 37:537-546 (2004). 


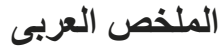

دور الفازوديل والانجسيوتنسين (-1-7) في الإعتلال الكلوي المستحدث عن طريق حقن البوروميسين في الفئران

الخلفية العلمية والهدف من البحث:تعد المتلازمة الكلوية حالة ربما تهدد الحياة و تتميز بكثرة البروتين فى البول ، نقص البومين

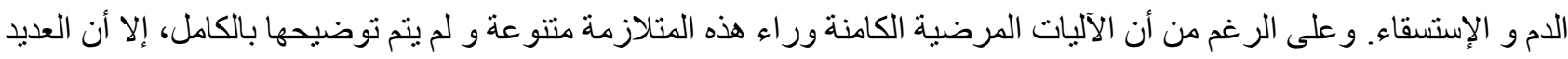
من العمليات الجزيئية قد أدخلت لتفسير الفيزيولوجيا المرضية منها أنظمة الروكاينيز و الرينين أنجيوتتسين. فى هذه الدر اسة قمنا بتقييم ما اذا كان تنبيط نظام الروكاينيز من خلال تناول الفازوديل و التنخل في نظام الرينين أنجيو تنسين من خلال تناول (AVE0991)

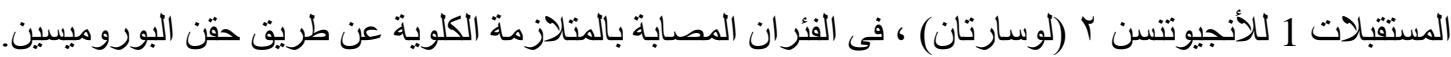
طرق البحث: تم إجراء البحث على خمسين من ذكور الفئران البيضاء وقد تم تقسيم هم إلى خمس مجموعات تتكون كل مل منها من

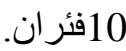

1. المجموعة الضابطة: تم اعطائها محلول ملح بتركيز 0.9 ٪ ،

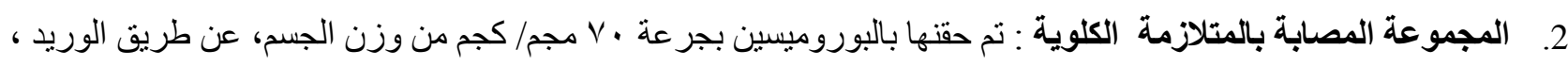

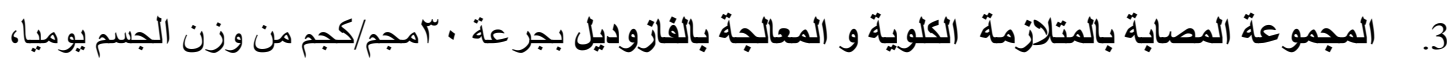

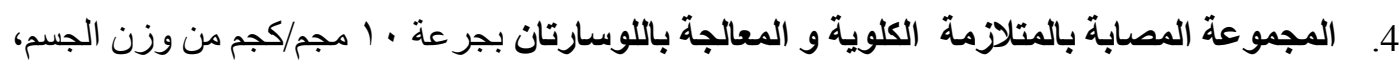

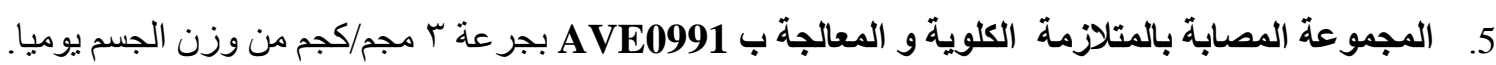

تم إعطاء الأدوية لجميع المجموعات عن طريق الفم ، من اليوم السابع و حتى اليوم الر ابع عشر من حقن البوروميسين.

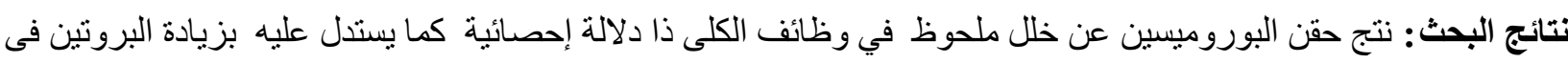
البول، نقص البومين الدم، نقص تصفية الكرياتينين، ارتفاع الكرياتينين فى مصل الدم مصحوباً بإرتفاع ـ ذا دلالة إحصائية ـ في

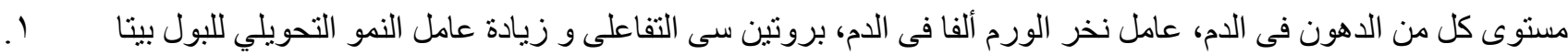

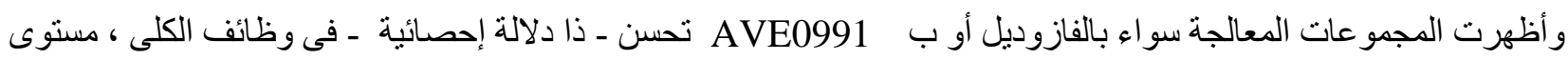

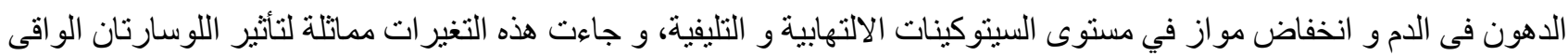
للكلى. الخلاصة: نستتنج من هذه الدر اسة أن كل من مسار ات الروكاينيز و الرينين أنجيوتنسن تساهم في إعتلال الكلى الناتج عن المتلازمة الكلوية وأن التدخل بتهيئة هذه المسار ات يمثل حماية للكلى ، و بالتالي يمثل طريقة جديدة لعلاج المتلازمة الكلوية. 